\title{
THE PRE-History OF THE ENGLISH LAWS ACT 1858: MCLIVER V MACKY (1856)
}

\author{
David V Williams*
}

\begin{abstract}
The English Laws Act 1858 declared the reception date for the arrival of English law and statutes of general application in New Zealand to be 14 January 1840. This Act was passed because the New Zealand Supreme Court had decided the Wills Act 1837 (UK) did not apply in New Zealand. New Zealand was annexed to the British Empire as a dependency of New South Wales with a reception date in 1825 or 1828. The Supreme Court case that so decided was McLiver v Macky (1856). The New Zealand Law Foundation's 'Lost Cases Project' ascertained that this judgment was fully reported in an Auckland newspaper - The Southern Cross. This article examines the facts of the case and the reasoning of Acting Chief Justice Stephen as to the basis for British sovereignty in New Zealand and the application of English law to British subjects here.
\end{abstract}

The only treaty which ever existed between the Crown and the inhabitants of New Zealand (the Maories) was that of Waitangi. But was that a cession of the territory? So far from it, that that treaty recognises the continued right of the Maories over all the lands, and provides that no sales of the lands shall be made by the Maories, except to her Majesty. And, for this last mentioned reason, New Zealand cannot be considered as a plantation, acquired by occupancy. ${ }^{1}$

\section{BACKGROUND}

In 1858 the New Zealand legislature passed a declaratory statute for all purposes to be cited as The English Laws Act 1858. According to the Act's preamble, the laws of England existing on 14 January 1840 "have until recently been applied in the administration of justice in the Colony of New Zealand so far as such laws were applicable to the circumstances thereof." It went on to recite that

* Professor of Law, Faculty of Law, University of Auckland. My thanks to all members of the New Zealand Lost Cases project funded by the New Zealand Law Foundation and to the Law Faculty of Victoria University of Wellington for hosting the Leading Cases conference in June 2010. The article is my responsibility but I have been greatly assisted by archival and other research inquiries conducted by Mark Hickford and Megan Simpson, and conversations with Shaunnagh Dorsett.

1 "Supreme Court" The Southern Cross (Auckland, 18 November 1856) at 4. 
"doubts have now been raised as to what Acts of the Imperial Parliament passed before" that date are in force in the Colony and "it is expedient that all such doubts should be removed without delay." The only substantive section in the Act - s 1 - read:

The laws of England as existing on the $14^{\text {th }}$ day of January 1840 , shall, so far as applicable to the circumstances of the said Colony of New Zealand, be deemed and taken to have been in force therein on and after that day, and shall continue to be therein applied in the administration of Justice accordingly.

What were the doubts that had been raised, and what were the reasons for deeming 14 January 1840 to be the date for the reception of English law in New Zealand? In an article published in 1988, based on my doctoral thesis, I referred to an unreported case that supplied the only information I could then find on the background to the Act. ${ }^{2}$ This unreported case was discussed in the 1877 judgment of the Supreme Court in Parata v Bishop of Wellington: ${ }^{3}$

At Auckland, in 1858, it was held by Acting Chief Justice Stephen that New Zealand had formed part of the colony of New South Wales from the time of the foundation of the latter, with the result that the English Wills Act of 1835 was not in force here, the statute having been passed since the country became a British possession. The decision imports that the title of the Crown to the country was acquired, jure gentium, by discovery and priority of occupation, as a territory inhabited only by savages. It led to the passing of the English Laws Act, 1858, the purpose of which was to fix the date which should be considered in our Courts as the foundation of the colony.

Archivists informed me that there was no possibility of finding primary source information about this case - supposedly decided in 1858 - as the Auckland court files for that period had been disposed of by a judge or official with no inkling of the importance that information in old records might hold for future historians. The parliamentary record was of no help for finding out precisely why the English Laws Act was passed in 1858. The Bill passed through three readings in the Legislative Council and then three readings and a Committee consideration in the House of Representatives between 15 April and 21 April. For none of those seven debates was any substantive discussion about the Bill recorded in Hansard. ${ }^{4}$

When the New Zealand Law Foundation agreed to fund the "New Zealand's Lost Cases Project" based at the Victoria University of Wellington, ${ }^{5}$ I immediately requested a search for any information that might be located about the Wills Act judgment of Stephen ACJ and his findings on

2 David V Williams "The Foundation of Colonial Rule in New Zealand" (1988) 13 NZULR 54.

3 Parata v Bishop of Wellington (1877) 3 NZ Jur (NS) 72 (SC) at 78. (This case is usually incorrectly cited as Wi Parata. In law reporting, it is not the norm to include a diminutive version of the plaintiff's first name when citing a court case.)

4 (1856-1858) NZPD 383-384, 386 and 401.

5 New Zealand Lost Cases Project <www.victoria.ac.nz/law/nzlostcases>. 
the reception of English law in New Zealand. To my intense delight the Project's researcher, Megan Simpson, ascertained that though Stephen had died in January 1858, he had delivered judgment on these matters in the case of McLiver v Macky in 1856. Some of the evidence of witnesses and the submissions of counsel, and the entire judgment of the court appeared in September, October and November 1856 issues of The Southern Cross newspaper published in Auckland. ${ }^{6}$ The fact that the case was eventually "settled out of court" was mentioned in a December issue. ${ }^{7}$ This newspaper source is now conveniently available through a magnificent digitised record - "Papers Past" created by the National Library of New Zealand. ${ }^{8}$

\section{THE LAWYERS PARTICIPATING IN MCLIVER V MACKY}

The Acting Chief Justice of New Zealand sitting in Auckland, the capital of the Colony in 1856, was Sidney Stephen. He was a member of a family that was greatly devoted to the law and to serving the interests of the British Empire both at home and in far-flung reaches of the Empire including India, St Kitts, New South Wales, Van Diemen's Land and New Zealand. A biographer observed: "Stephen was born to the law almost to the point of having been swaddled in a stuff gown."9 The Stephen families were closely associated with the slavery abolition movement and then the aborigines protection movement. Sidney was the son of John Stephen, a judge in St Kitts and then in New South Wales - where for a time he was Acting Chief Justice. His younger brother Alfred was Chief Justice of New South Wales from 1844 to 1873, and amongst Alfred's sons three became lawyers (one of them a judge). ${ }^{10}$ A cousin of Sidney and Alfred was another lawyer, James Stephen - who served in the important role of Under-Secretary in the Colonial Office from 1836 to 1847. In that position James Stephen played a leading role in moulding the imperial government's various moves towards the annexation and then administration of New Zealand. He also had influence in the appointment of several of his relations to posts in the colonial judiciary. His son James Fitzjames Stephen served on the Viceroy's Council in India and drafted a number of codifications of English law (including the criminal code applied in many colonies - Queensland and New Zealand being early examples).

6 "Supreme Court, Civil Sittings" The Southern Cross (Auckland, 26 September 1856) at 3; "Supreme Court" The Southern Cross (Auckland, 14 October 1856) at 3; "Supreme Court" The Southern Cross (Auckland, 14 November 1856) at 3; "Supreme Court" The Southern Cross (Auckland, 18 November 1856) at 3-4.

7 "Local Intelligence, Supreme Court" The Southern Cross (Auckland, 12 December 1856) at 3.

8 Papers Past <http://paperspast.natlib.govt.nz>. Papers Past contains more than one million pages of digitised New Zealand newspapers and periodicals. The collection covers the years 1839 to 1932 and includes 58 publications from all regions of New Zealand.

9 R Jones "Stephen, Sidney (1797-1858) Judge" first published in AH McLintock (ed) An Encyclopaedia of New Zealand (1966) (Government Printer, Wellington, 1966) <www.teara.govt.nz>

10 "The extended Stephen family and their Australasian connections" (2008) 29 Cemetery Conversations 3, available at <www.foskc.org $>$. 
Another member of the same Stephen family made a significant indirect contribution to the decision in McLiver v Macky. Serjeant Henry John Stephen was the original compiler of materials that were published in 1834 by Charles Clark as A Summary of Colonial Law. ${ }^{11}$ As will be noted below, Stephen ACJ relied on this treatise extensively in his judgment. Later, HS Stephen himself published four volumes of New Commentaries on the Laws of England (partly founded on Blackstone). Volume I, published in 1841 retained Blackstone's text on the acquisition of colonies by conquest or by cession, or by occupation if they are "desert and uncultivated" along with the notion that: ${ }^{12}$

$\ldots$ if an uninhabited country be discovered and planted by English subjects, all the English laws then in being, which are the birthright of every subject, are immediately there in force. But this must be understood with very many and very great restrictions. Such colonists carry with them only so much of the English law as is applicable to their own situation, and the condition of an infant colony; such as, for instance, the general rules of inheritance, ...

Of the three possible options within imperial law as understood by English lawyers, the exact basis for British claims over New Zealand came to be an important issue in Sidney Stephen's 1856 judgment.

Sidney Stephen himself was educated at Charterhouse, articled in Lincoln's Inn and called to the Bar in 1818. He joined his family in St Kitts, and then moved with them to New South Wales. He practised in Sydney for a while. He is still remembered in New South Wales as the counsel for defendant in $R v$ Murrell in 1836 who argued that aboriginal laws, not English or colonial law, ought to be applicable in cases involving only aboriginals. ${ }^{13}$ When his younger brother Alfred became Attorney-General of Van Diemen's Land Sidney moved to Hobart. Unhappily the Stephen brothers fell out with Montague J of the Colony's Supreme Court and one of the consequences was that Sidney was disbarred in 1842 . He then became a squatter in Victoria and vocal member of the anti-transportation movement. When the Privy Council eventually cleared his name in 1847 and rescinded his disbarment, ${ }^{14}$ Sidney sought judicial preferment. No vacancy occurring in South

11 C Clark A Summary of Colonial Law (Sweet, Maxwell and Stevens, London, 1834).

12 HS Stephen New Commentaries on the Laws of England (partly founded on Blackstone) (Henry Butterworth, London, 1841) vol I at 98.

$13 R v$ Murrell and Bummaree (1836) Supreme Court of NSW, available at <www.law.mq.edu.au>; Bruce Kercher "Native Title in the Shadows: The Origins of the Myth of Terra Nullius in early New South Wales Courts" in Gregory Blue, Martin Bunton and Ralph Croizier (eds) Colonialism and the Modern World: Selected Studies (M E Sharpe, Armonk (NY), 2002) 100.

14 "Sidney Stephen, Esquire: copies or extracts of correspondence between the Colonial Office and ... authorities in Australia, Van Diemen's Land and New Zealand, relating to the removal of Mr Sidney Stephen from the bar of Van Diemen's Land, and his appointment as a judge of the Supreme Court of New Zealand" (House of Commons, London, 1850); Re Stephen (1847) Privy Council: 〈www.law.mq.edu.au>. 
Australia, his first choice, he accepted appointment to the Supreme Court of New Zealand in 1850 and was appointed to be the first judge based in Dunedin. The appointment was somewhat controversial. Nelson settlers were affronted that their thriving settlement was overlooked in favour of the then small settlement in Dunedin. ${ }^{15}$ On the other hand, the law-abiding Scottish Free Church settlers in Otago saw no need for any judge in their district and, in particular, no need to pay the sum of $£ 800$ per annum by way of salary from the meagre resources of their provincial exchequer. In 1852 Stephen was transferred to Wellington. In early 1856 he moved to Auckland when the health of the first Chief Justice, William Martin, broke down and Martin left the Colony for a period. Stephen was now Acting Chief Justice and rather hoped to be appointed the second Chief Justice. That was not to be and when he died in January 1858 a newspaper obituary opined that "a profound sense of Government injustice hurried him to his grave" when "some obscure English lawyer called Arney" was appointed Chief Justice. ${ }^{16}$

The lawyers appearing before Stephen ACJ in the McLiver v Macky proceedings were both lawyer politicians in Auckland. Counsel for the plaintiff was Frederick Ward Merriman who in 1844 founded the firm that was known as Merriman and Jackson in 1856 and is now known as Jackson Russell. ${ }^{17} \mathrm{He}$ was a foundation member of the House of Representatives from 1854 to 1859 and also served on the Auckland Provincial Council from 1855 to $1861 .{ }^{18}$ Counsel for the defendant was Frederick Whitaker. He is best known for being Premier of the Colony at the time of the Waikato wars and the passage of confiscation legislation, including the New Zealand Settlements Act $1863 .{ }^{19}$ However, he was a leading political leader of the Auckland settler community for many decades from his appointment to the Legislative Council in 1845 until his death in 1891. In addition to many other political, legal and business responsibilities over those years, he was AttorneyGeneral of the Colony in seven ministries for many of the years between 1856 and 1865 and again for much of the period from 1876 to 1891 . He twice served as Premier. ${ }^{20}$ The modern law firm Bell Gully traces one branch of its origins to Whitaker's sole practice in Kororareka, and then in Auckland and to the partnership he founded with Thomas Russell in 1861. The newspaper reports of McLiver v Macky and the court's judgment constantly refer to Whitaker as Attorney-General. I

15 Editorial The Nelson Examiner, and New Zealand Chronicle (Nelson, 1 June 1850) at 54.

16 Jones "Stephen, Sidney", above n 9.

17 Information on the history of the firm can be found at <www.jacksonrussell.co.nz>.

18 "Mr. Frederick Ward Merriman" in The Cyclopedia of New Zealand [Auckland Provincial District] (Cyclopedia Company, Christchurch, 1902) <www.nzetc.org>.

19 M Allen "An Ilusory Power? Metropole, Colony and Land Confiscation in New Zealand, 1863-1865" in R Boast and R Hill (eds) Raupatu: The Confiscation of Maori Land (Victoria University Press, Wellington, 2009) 110 at $120-131$.

20 RCJ Stone "Whitaker, Frederick 1812-1891" (2007) Dictionary of New Zealand Biography <www.dnzb.govt.nz>. 
assume, though the matter is not clear, that he was privately retained as counsel for the defendant in these proceedings.

\section{RICHMOND J WROTE THE PARATA JUDGMENT IN 1877}

Before turning to the substance of the McLiver v Macky litigation itself, it is worth noting a further find of legal historical significance that has flowed from the work of the Lost Cases Project team. This concerns the judgment in the Parata case. The "in banco" decision of the Supreme Court in the 1877 was delivered by Prendergast CJ and is often attacked as "notorious" for its "infamous" reasoning. I will not go into the wider merits (or otherwise) of the case here. I leave that for my forthcoming monograph devoted to the case. ${ }^{21}$ For a number of reasons relating to the conduct of the proceedings, the style of the judgment, the nature of the many issues pursued in the judgment and the public political record of the two judges, it became clear to me in the course of researching for that book that Richmond $\mathbf{J}$ - the other judge on the two person "in banco" bench - was the primary author of the Parata judgment. It was purely by dint of rules of precedence that it was publicly delivered by the Chief Justice as the senior member of the court on 17 October 1877 . My inquiry as to the primary authorship of the judgment first began when my perusal of Sir James Prendergast's Notebook disclosed no information at all about the Parata litigation for the day that hearings commenced: Friday, 13 July 1877. Sir James had written notes on submissions he had heard during a perjury trial on 10 October, and then the next case recorded in the consecutively numbered pages of his Notebook was a civil case heard on 16 July. ${ }^{22}$ It is evident from the New Zealand Jurist law report that the Chief Justice was on the bench on 13 July, and this is confirmed by a news report of that date in The Evening Post. ${ }^{23}$ Mark Hickford's inquiries in the Crown Law Office revealed this handwritten ink note at the foot of page 72 in the Office's copy of the New Zealand Jurist law report: ${ }^{24}$

21 David V Williams A Simple Nullity? The Wi Parata Case in New Zealand Law and History (Auckland University Press, Auckland, forthcoming 2011).

22 "Chief Justice Prendergast" Archives New Zealand, Wellington (ANZ), AAOM W3842/141/27, at 183-185 contains Prendergast's notes concerning $R$ v Morrison, a perjury trial held on Wednesday 10 July 1877. There are no entries for Thursday 11 July or for Friday 13 July - the day Parata $v$ Bishop of Wellington was argued. Page 186 contains notes concerning Cole v McKindy, a civil case heard by Prendergast on Monday 16 July 1877.

23 "Supreme Court in banco this day (before his Honor the Chief Justice and Mr Justice Richmond.)" The Evening Post (Wellington, 13 July 1877) at 2.

24 Letter from M Hickford to DV Williams (18 May 2010) indicated that Currie, the author of this note, worked in Crown Law from about 1925. He wrote AE Currie New Zealand and the Statute of Westminster (Butterworth \& Co, Wellington, 1944) and AE Currie Crown and subject: a treatise on the rights and legal relationship of the Crown and the people of New Zealand as set out in the Crown Proceedings Act, 1950 (Legal Publications, Wellington, 1953). 
This report should be checked by reference to corrections made in one copy of this volume in the Wellington Supreme Court Library and initialled by Richmond J according to Mr A E Currie.

Following up on that notation, there is indeed a volume in the library of the old Supreme Court - now the High Court - with numerous handwritten notations on the published law report. One of them is initialled "CWR" - the initials of C William Richmond. Amongst these corrections (I am pleased to record), the name of the case is inserted in the index of cases reported in the volume under the letter P rather than under W. CWR noted that Earl Grey's "Instructions" and "Notorious Regulations" were of 1846, not 1840; he amended the "English Wills Act" to be "of 1838" rather than "of 1835" (though actually it was passed in 1837!); he inserted and initialled some missing words - "wholly different from that" - on $\mathrm{p} 81$; and he made a number of other minor corrections. ${ }^{25}$ All this looks very much like the author of the judgment checking the printed report against his own personal copy of the original judgment for the benefit of judges using that law report in the future. Finally, and in my view conclusively, Megan Simpson located Richmond's Notebook in Archives New Zealand. It contains entries written by that judge for the hearing on 13 July and also for two other dates not noted by the New Zealand Jurist reporter, but one of which was briefly reported in the Evening Post ${ }^{26}$ when the Parata case came before the judges in $1877 .{ }^{27}$

\section{THE MISSING WILL OF HUGH MCLIVER}

Hugh McLiver, a Scot migrant owned property in New Zealand and made a will disposing of that property prior to leaving for California in 1849 . He died there in 1850 . The will was not produced to the court and the evidence before the court was that it had been destroyed in a fire in Sacramento, but what purported to be a copy of the will of the deceased was produced. This copy, it was alleged, was made by one Donald Munro, of Van Diemen's Land, at San Francisco, a short time after Hugh McLiver's death. The deceased's mother, Elizabeth McLiver, gave evidence to the Supreme Court:28

I am widow of John McLiver. I am 85 years of age. I was married in Islay between 50 and 60 years ago. I have had 9 sons and 3 daughters by John McLiver. John was the first; Hugh the second; Archibald the third; Charles the fourth; and Lachlan (the plaintiff) the fifth. Charles died when he was 8 years old; and Archibald when he was seven years old. It is 25 years since I heard of John; he was a clerk in Glasgow, and unmarried. He turned a wee foolish (took to drinking) and left the country. I never heard where he

25 The Richmond annotated volume of (1877) 3 New Zealand Jurist (New Series), which is now in the High Court Library, has the handwritten notation " S C Library 28-3-79" on the title page of the volume.

26 The Evening Post (Wellington, 15 August 1877) at 2.

27 "Judge Richmond" ANZ, AAOM W3842/172/8 at 29 and 34-35 and at 38-39 contains Richmond's handwritten entries on the Parata hearings held on 13 July, 1 August and 15 August 1877.

28 "Supreme Court" The Southern Cross (Auckland, 26 September 1856) at 3. 
went except from a schoolfellow who said he thought he had seen him on board the 'Thunderbolt', in Egypt.

According to the Acting Chief Justice there were two issues before the court: ${ }^{29}$

1st. Whether the plaintiff was the heir at law of one Hugh McLiver, deceased, who held a grant for this land; and, secondly, whether the said Jane McLiver, the widow of the deceased, was entitled to the same under the Will of the said Hugh McLiver. The action was, in reality, between one claiming as heir at law, and the other as devisee; Macky being only a nominal defendant.

The plaintiff, in an action for ejectment, was Lachlan McLiver. If his drunken and missing eldest brother could be presumed in law to be dead, then Lachlan as the oldest surviving son would be Hugh's heir-at-law and he would succeed to Hugh's estate unless a valid will provided otherwise. Jane McLiver, Hugh's widow, was the sole beneficiary under his putative will. The defendant on the record was Thomas Macky. He was Jane's tenant and he was in possession of the property in question in these proceedings. On the disputed facts in the case, there was no doubt of the judge's views. Part of his summing up to the jury read: ${ }^{30}$

The usual course in cases of wills was to produce the will itself, for no oral evidence was to be compared to written. If it was not forthcoming, then secondary evidence would be taken for primary; but it was necessary that every effort should first have been employed to find out that primary evidence. It was also necessary that the copy of a will should be subjected to the same kind of proof as an original. Under the statute, Vic. 1, a will required to be signed and delivered by the testator in the presence of two witnesses, who, at his request, in his presence, and in the presence of each other, attested such signature and delivery. If proof was requisite of this formality having been complied with in reference to an original document, the same proof was not less necessary in reference to a mere copy. That was the law, and the question was, had any of that kind of proof been offered to the jury? There had been no such evidence; and, if not, then all other evidence was illusive. But what did that other evidence amount to? Two documents were produced, purporting to be copies of a will executed by Hugh McLiver before he left the colony, attested by Messrs. Conry and O'Brien, and given by McLiver to his wife. These copies did not quite agree with each other, which he did not regard of much consequence, as being, in all probability, a mere error in copying. They were made by Mr. Munro, who was certified by the British Consul to be a person of credit, but he (the learned Judge) would not be chargeable with want of charity if he said that no great attention should be paid to the certificate of the British Consul, residing at that time in such a place as Sacramento or San Francisco. Weight might also be attached to the fact of the copy produced being copied from that in the Registrar's office, but that copy had been improperly registered, and was to have no effect. Before Mrs. McLiver went away, she had shown the will to Marshall, and although he believed the copy produced to be of the same effect, what dependence was to

29 "Supreme Court" The Southern Cross (Auckland, 14 November 1856) at 3.

30 "Supreme Court" The Southern Cross (Auckland, 26 September 1856) at 3. 
be placed on the memory of an individual as to the contents of a document he had seen, on one occasion,

several years ago?

The newspaper report then remarked the outcome of the trial:

The jury then retired, and, after an absence of five minutes returned - much to the surprise of those who

had heard the judge's charge - a verdict for the defendant. They found that the plaintiff was heir-at-law,

but that the will was valid.

This surprising outcome - presumably based on jurors' sympathy for the plight the widow might be in if she did not succeed to her husband's property interests - was challenged in an application for a new trial based on five grounds. The plaintiff argued that the jury verdict was contrary to the evidence, contrary to law, contrary to justice, contrary to the opinion of the judge and, fifthly, adding a more technical but ultimately pivotal point - even if the will was proved it had been attested by only two, not by three witnesses. Stephen ACJ ordered a retrial after an extensive discussion of case law on whether it was proper to leave to a jury a question concerning the validity of an unexecuted copy of a will. Concerned as I am with the pre-history of the English Laws Act 1858 , my focus on the fifth ground for a new trial and the concluding paragraphs of the judgment on the reception date for English law in the New Zealand Colony.

\section{$V$ HOW DID NEW ZEALAND BECOME A BRITISH COLONY?}

As quoted above, in his summing up to the jury in the first trial Stephen ACJ clearly assumed that the Wills Act 1837 was in force in New Zealand. He spoke (slightly inaccurately) of "the statute, Vic. 1" and its requirement for wills to be attested in the presence of two witnesses. This assumption was questioned by the plaintiff in the application for a new trial. A rule nisi having been granted, the defendant was called upon to shew cause why a new trial should not be granted. The newspaper report of the respective arguments of counsel on the fifth ground read: ${ }^{31}$

The fifth point was one of much legal intricacy, but which the Attorney- General entered into at some length. It was simply what Act of Parliament - whether the Wills Act of Vict 1, or previous statutes was in force in the colony. The former requires a will to be attested by two witnesses; the latter by three. The learned counsel contended that when New Zealand, in 1840, became a British dependency, the Act of Vict. 1, even although it did not extend to Scotland, became ipso facto the law of the colony. He considered then, that the rule should be discharged, and prayed the Court accordingly.

Mr. Merriman in reply ... contended that the Act of Vict. 1, was not in force here, it not having been adopted by the local legislature. It was a startling conclusion to draw, but he feared that it was so, and that no will was valid, which was not attested by three witnesses.

31 "Supreme Court" The Southern Cross (Auckland, 14 October 1856) at 3. 
Both the Attorney-General and Mr. Merriman cited numerous authorities in support of their respective arguments, which his Honor said he would examine, and give his decision on a future day.

When the Acting Chief Justice came to give his decision on this point, he first inquired as to how New Zealand came to acquired as a British colony. It is a matter of some interest that discussion on the application of English law to a colony in this case made no reference whatsoever to the American texts of Kent and Story that were extensively discussed in Symonds (1847) and Parata (1877). Unlike Chapman and Richmond in those cases, Stephen drew heavily on the treatise on colonial law by Charles Clark (derived from materials prepared by Serjeant HS Stephen) mentioned above. The newspaper report refers to this book as "Clarke": 32

There is now one point remaining to be considered, viz., whether the Act $7 \mathrm{Wm} .4$ and 1 Vict. c. 26, is in force within this Colony. All writers on colonial law agree in classifying Colonies under three heads: 1 st "those acquired by conquest; 2ndly, those acquired by cession under treaty; 3rdly, those acquired by occupancy, viz., where an uninhabited country is discovered by British subjects, and is upon such discovery adopted or recognised by the Crown as part of its possessions" see Clarke p. 4. He then goes on to say, "In cases of conquest or cession, the conquered or ceded country retains its former laws, till they are changed by competent authority." (Propriety and charter governments might he considered, but as Clarke observes. "There is at present none such in the British Colonies" p. 3, note 3. But if there were, they must have come under one of the heads above mentioned in their original acquisition.) Clarke says. "'In giving a new constitution to a conquered, or ceded Colony, if the crown provides, (as has hitherto usually been the case), that a Representative Assembly shall be summoned among the inhabitants of the Colony, with the power of making laws for its interior government, it has been decide that the Crown cannot afterwards (that is, after such Assembly shall have been constituted) exercise, with respect to such Colony, its former right of legislation. It has impliedly renounced that right, by the appointment of a legislative power within the Colony itself." Clarke p7. He then goes on to say, "In the case of a Colony acquired by occupancy, which is a plantation in the strict and original sense of the word, the law of England then in being, is immediately, and ipso facto, in force in the new settlement, and, such a colony is not subject to the legislation of the Crown, for the King cannot pretend, in that case, to the rights of Conqueror; but the subjects of Great Britain, the discoverers and first inhabitants of the place, carry therewith them their own inalienable birth-right, the laws of their Country. But they carry with them only, so much of these laws as is applicable to the condition of an infant Colony, such, for instance, us the general rules of inheritance, and protection from personal injuries. For the artificial refinements and distinctions incident to the property of a great and commercial people (such especially as are enforced by penalties), the mode of maintenance for the established clergy, the jurisdiction of the spiritual Courts, and a multitude of other provisions, are neither necessary nor convenient for them, and therefore not in force." And in a note (Clarke, p. 8, n. 4) he says, "The Common law of England is the Common Law of 
the plantations; and all statutes in affirmance of the Common law passed in England, antecedent to the settlement of any Colony are in force in that Colony.

In seeking to apply Clark's principles on colonial law to New Zealand, Stephen gave an interpretation of the significance of the Treaty of Waitangi which has not featured in subsequent considerations of the legal status of the Treaty. Because it is such an interesting, and perhaps plausible, understanding of the Treaty's significance, I quoted it above prior to the beginning of this article. The full text of his remarks is as follows: ${ }^{33}$

It is not easy to determine, under which of the three before mentioned classes of Colonies New Zealand must be considered. It is beyond a doubt, not a conquered colony. Is it a ceded Colony? I cannot consider it as such; certainly not within the meaning of the writers on Colonial law. The only treaty which ever existed between the Crown and the inhabitants of New Zealand (the Maories) was that of Waitangi. But was that a cession of the territory? So far from it, that that treaty recognises the continued right of the Maories over all the lands, and provides that no sales of the lands shall be made by the Maories, except to her Majesty. And, for this last mentioned reason, New Zealand cannot be considered as a plantation, acquired by occupancy.

This provides a rather different approach to the Treaty of Waitangi compared to that usually attributed to colonial judges in the nineteenth century. The "a simple nullity" dictum of the Parata court is what usually comes to mind. Few people are aware that, five years before Parata, Johnstone $\mathrm{J}$ as commissioner under the Lundon and Whitaker Claims Act 1871 wrote that the Treaty of Waitangi "has been assumed by the Imperial Parliament and the Legislature of the Colony as the basis of the policy and legislation of both respecting the aboriginal inhabitants of New Zealand."34 Or, that just seven years after Parata, in the Supreme Court case of Mangakahia v The New Zealand Timber Company Ltd, Gillies J doubted the now infamous dictum: ${ }^{35}$

Theoretically the fee of all lands is in the Crown, subject nonetheless to the "full, exclusive and undisturbed possession of their lands," guaranteed to the native by the treaty of Waitangi which is no such "simple nullity," as it is termed in Wi Parata v. The Bishop of Wellington quoted in argument in this case.

Equally few people are aware that the Supreme Court in $R v$ Symonds - usually praised when Parata is condemned - refused to respond to detailed submissions based on the Maori text of the Treaty put forward by Bartley, counsel for McIntosh (who had purchased from Maori the land in

33 Ibid.

34 AJ Johnston "The Commissioner's Decision" (15 April 1872) [1872] AJHR G-6 at 6-7.

35 Mangakahia $v$ The New Zealand Timber Company Ltd (1884) 2 NZLR 345 (SC) 350. 
question in that case). ${ }^{36}$ Instead the Symonds judgments insisted on a narrow view of the land guarantees in the Treaty of Waitangi. They were seen as merely declaratory of Maori aboriginal rights and the court refused to take any account of the Treaty's Maori text. ${ }^{37}$ Nor is it well known that on the same page of the Parata report as the "a simple nullity" dictum with respect to the Treaty as an instrument ceding sovereignty, the judges stated that the "sovereign of the settling nation" owed duties, "as supreme protector of aborigines", of securing Maori "against any infringement of their right of occupancy". ${ }^{38}$ The truth is that there are a number of diverging views on the status and significance of the Treaty of Waitangi to be found in pronouncements by members of the colonial judiciary in the nineteenth century. The recovery of the McLiver v Macky judgment now adds a further complexity to our understanding of that aspect of our legal history.

Returning to the views of Stephen ACJ, the implications of the judge's views quoted above are that the Treaty of Waitangi undermined any claims to British sovereignty based on discovery and occupation. It was accepted by Stephen that New Zealand was not acquired by conquest, nor was it acquired by cession. New Zealand could not be acquired by occupancy as an "uninhabited country" discovered by British subjects because it is in fact inhabited by "Maories", and their continued rights over "all the lands" had been recognised by Her Majesty the Queen in a treaty. Following this reasoning, one might arrive at the uncomfortable conclusion that there were no valid grounds in colonial law for the lawful acquisition of New Zealand from the indigenous Maori as a British territory. This is reminiscent of the argument mentioned previously that Stephen had advanced in the Murrell case in Sydney in 1836 - English law did not apply to aborigines in New South Wales Colony. Leaving such large questions in abeyance, however, the Acting Chief Justice quickly moved to safer ground based on Blackstonian doctrine as expounded by Clark: ${ }^{39}$

Still, so far as British subjects are concerned, without regard to the rights of the Crown over the general lands of New Zealand, whether New Zealand be in fact acquired by the Crown, in either, or neither of the above mentioned modes of acquiring Colonies, I should hold that those subjects carry with them the Common law of England, and so much of the statute law of England as is applicable to their circumstances and condition, and as was passed prior to those subjects having a Legislature of their own in such colony.

36 "Important Case. Waiver of the Crown's Right of Pre-emption - Treaty of Waitangi" The New-Zealander (Auckland, 8 May 1847) at 3; continued in Supplement to The New-Zealander (Auckland, 8 May 1847). See M Hickford "Vague Native Rights to Land: British Imperial Policy on Native Title and Custom in New Zealand, 1837-53" (2010) 38 Journal of Imperial and Commonwealth History 175, at 190-193.

37 The Queen (on the prosecution of CH McIntosh) v Symonds (1847) [1840-1932] NZPCC 387.

38 Parata v Bishop of Wellington, above n 3, at 78.

39 "Supreme Court" The Southern Cross (Auckland, 18 November 1856) at 4 
What then was the common law or statute law that applied to the British subjects before the court and to the late Hugh McLiver when he drew up his will?

\section{WAS THE WILLS ACT 1837 (7 WILL IV AND 1 VICT C 26) IN FORCE IN NEW ZEALAND IN 1856?}

The argument advanced by Merriman for the plaintiff in support of the fifth ground for a new trial was this: for any will to be valid in New Zealand it needed to comply not with the Wills Act 1837 (7 Will IV and 1 Vict c 26), which was not in force in New Zealand, but with the Act 29 Cha II c 3 ("An Act for Prevention of Frauds and Perjuryes", 1677). The latter Act required three witnesses to be present at the attestation of a will rather than the two witnesses stipulated in the 1837 Act. Betraying his West Indian background, Stephen approached the matter this way: ${ }^{40}$

The first charter granted to New Zealand is dated, November, 1840. Had there been no statute in force within New Zealand prior to that date, I should have no difficulty in saying that the Act, 7 Wm , 4 and 1 Vic. c. 26 having passed in 1837, was in force within this colony, as being applicable to its circumstances. I should regard it as in connection with the statute 29 , Charles 2, which is a statute for the prevention of "frauds and perjuries," and which has always been recognised in the West Indian Colonies, as in force there. I believe that that doctrine has been acknowledged in our Courts in England, though I cannot find the authority. But the ground on which it has been held, is that, as the prevention of fraud, or, perhaps more strictly speaking, fraud itself, is punishable at common law, the statute of 29 , Chas. 2, being in affirmance of the common law, would be in force in those colonies, on their being acquired by the Crown, and until they had repealed it by their own Legislatures. Upon this ground, as being in affirmance of the common law, and in connection with the statute of Frauds, I should have held that the Act 7 Win, 4, and 1 Vict. c. 26., was in force in New Zealand.

But, inquired the judge, "had New Zealand no Legislature of its own till November 1840?" Few people think of Sydney as the first colonial capital of New Zealand and my 1985 article "The Annexation of New Zealand to New South Wales in 1840" - also drawn from my doctoral thesis is one of my least cited articles. ${ }^{41}$ The answer, though, to the judge's question is that New Zealand had had a colonial legislature applying law to it prior to November 1840. The legislature of New South Wales, to which New Zealand was annexed as a dependency earlier in 1840, had been the legislature for New Zealand and indeed had passed an Act specifically applying New South Wales law to the new dependency - 3 Vic No 28 - that came into force on 16 June 1840. That Act was continued in force by the very first Ordinance passed by the New Zealand legislature following the

40 Ibid.

41 DV Williams "The Annexation of New Zealand to New South Wales in 1840: What of the Treaty of Waitangi?" (1985) 2 Aust J of L \& Soc 41. 
erection of New Zealand as a separate colony. ${ }^{42}$ This 1841 Ordinance was repealed and New South Wales law was explicitly disapplied by a further Ordinance in $1842 .{ }^{43}$ In joyful celebration of the 1842 removal of the "penal taint" from this "free" colony, the New Zealand Company settlers in Wellington held a public dinner at Barrett's Hotel. ${ }^{44}$ The thing is, though, that the reception of English laws and statutes of general application is a once-only event in the British imperial history of each colony. One body of English law could not be replaced by different body of English law from a later date than the original reception except by the passage of a local statute. An example of such a later statute was the New Zealand legislature's English Acts Act 1854. This explicitly applied a number of post-1840 imperial Acts to New Zealand - including, as it happens, the United Kingdom's Wills Amendment Act 1852. So, as at 1856, the 1852 Amendment Act certainly applied here, but was the principal 1837 Act in force in the Colony? No: ${ }^{45}$

The Charter of November, 1840 was granted by virtue of the Act 3 and 4, Vic. (August 1840). That Act is entitled, "An Act to continue until the 31 st day of December, 1841, and to the end of the then next session of Parliament, and to extend the provisions of an Act to provide for the administration of justice in New South Wales and Van Diemen's Land, and for the more effectual Government thereof, and for other purposes relating thereto ;" and it recites an Act, passed in the 9th Geo. 4, entitled "an Act to provide for the administration of justice in New South Wales and Van Dieman's Land, and for the more effectual Government thereof, and for other purposes relating thereto;" and it also recites that "that last mentioned Act had been since continued, and in the last session of Parliament had been further continued, with certain amendments."

The first section then continues the last recited Act, until 31st December, 1841.

The second recites thus, "Whereas the said colony of New South Wales is of great extent, and it may be fit that certain dependencies of the said colon y should be formed into separate colonies, and provisions should be made for the temporary administration of the Government of any such newly erected Colony;" and then enacts that it shall " be lawful for her Majesty, by letters patent, \&c, to erect into a separate colony or colonies, any Islands, which now are or which hereafter may be comprised within, and be dependencies of the said Colony of New South Wales." [Emphasis in original] The Charter of 1840 recites this last recited Act, and also recites, "and whereas the Islands of New Zealand, at the time of passing the above recited Act, were comprised within, and were dependencies of the said colony of New

42 An Ordinance to declare that the laws of New South Wales so far as they can be made applicable shall extend to and be in force in Her Majesty's Colony of New Zealand 18414 Vict No 1.

43 An Ordinance to repeal an Ordinance enacted by the Governor of New Zealand, with the advice and consent of the Legislative Council thereof, whereby the Laws of New South Wales were declared to extend to and be in force in the Colony of New Zealand 18425 Vict No 19. By s 3 this Ordinance came into force on 25 April 1842.

44 Williams "The Annexation of New Zealand", above n 41, at 54-55.

45 "Supreme Court" The Southern Cross (Auckland, 18 November 1856) at 4. 
South Wales," and goes on to say, "in pursuance of the said recited Act, and in exercise of the powers thereby in us vested," her Majesty did, by her said charter, erect the said Islands of New Zealand into a separate colony.

It is clear, therefore, that New Zealand was, at the time of the passing of the Act of $7 \mathrm{Wm} .4$ and 1 Vict. c. 26., a dependency of New South Wales, and subject to the Legislature of New South Wales, and consequently that Statute not being in force in New South Wales when the 9th Geo. 4 was passed, nor made to be so there when the Charter of 1840 was granted, it never was in force within this Colony.

If, however, there was an Act, passed in New South Wales, at any time before the grant of that Charter, to extend the Act of $7 \mathrm{Wm} .4$ and 1 Vict. c. 26 to New South Wales, then the Ordinance of New Zealand. September 2, No. 19 (passed 15 March, 1842.) by which '"All Laws, Acts, or Ordinances of New South Wales, which theretofore had been in force in this Colony, were repealed," would have repealed it. But the $7 \mathrm{Wm}, 4$ \& 1 Vict. c.26 was not, I believe, then in force in New South Wales; and the second section of this last Ordinance enacts, that, "No Law, Act, or Ordinance of New South Wales shall hereafter be of any force or effect whatsoever, within the Colony of New Zealand."

The result then is that as the Act, now under consideration, being passed in 1837, was not in force in New South Wales, when the 9th Geo. 4, (1827,) was passed; it was not in force in New Zealand, which, was then a dependency of that Colony; and, as it continued such dependency until the Charter of 1840, the Act could not be in force in New Zealand, unless it had been enacted by the Legislature of New South Wales in that interval, or at least before the repealing Ordinance of 1842. But if it had been enacted by that Legislature, and thereby had formed part of the New South Wales laws, in force within New Zealand, then the repealing Ordinance of 1842 would have repealed it, so that, so that quácunque viá datum, the Act 7 Wm. 4 and 1 Vict. c. 26, not having been passed within this Colony, by a Legislature of its own, it is not in force in New Zealand.

Readers aware that Australians celebrated a bicentenary in 1988 might note that the establishment of the penal colony when the first British ships reached the continent on 26 January 1788 was not considered the date of reception of English law. Rightly so - the administration of the penal colony in its earliest years bore but faint resemblance to the norms of English law. The reception statute mentioned by the judge -9 Geo IV c 83 - was not in fact enacted in 1827. After passage in the New South Wales legislature in 1827, the Governor reserved it for Her Majesty's assent or disallowance in London. It came into force on the date of the royal assent -25 July $1828{ }^{46}$ Thus 1828 was the reception date for English law in New South Wales and therefore, by the judge's reasoning, that was the reception date for the New Zealand dependency as well. The Wills Act 1837 was not part of New Zealand law.

46 Williams "The Foundation of Colonial Rule", above n 2, at 63. 
What then about the validity of wills made in the Colony prior to this unexpected decision? The Acting Chief Justice appeared not too concerned: ${ }^{47}$

It is well that this question has been considered at this time, as the evil may be remedied for the future.

At present, I believe, that not above one dozen wills, have been brought before me to be proved and with only two or three exceptions, the property is inconsiderable. Mischief may be prevented by having new wills drawn, attested by three witnesses; the other provisions of the Statute 29, Charles 2, (the law now in force in New Zealand as to wills) being more liberal than those of $7 \mathrm{Wm}$. 4, and I Vict. c.26.

This statement by Stephen confirms the paucity of wills made in early colonial New Zealand. This was a matter commented on during the Leading Cases Conference. ${ }^{48}$ Presumably the generally young pioneers from non-privileged backgrounds had little knowledge of, or care for, legal instruments such as wills.

\section{THE REMEDY FOR THE FUTURE: DEEMING 14 JANUARY 1840 TO BE NEW ZEALAND'S RECEPTION DATE}

At the outset of research for this article I was unsure why it took from late 1856 to mid 1858 to provide the remedy foreshadowed by the judge in McLiver $v$ Macky. In fact, though, the legislation was enacted at the first possible opportunity after the decision of the Acting Chief Justice. The second parliament of the General Assembly, as the colonial legislature was known, adjourned its first session on 16 August 1856 prior to the decision in McLiver v Macky. The General Assembly did not meet at all in 1857. The second session of the second parliament was opened on 10 April $1858{ }^{49}$ Just five days later, on 15 April, Whitaker - counsel for the losing defendant and AttorneyGeneral - introduced the English Laws Bill as a government measure into the Legislative Council. It passed through all stages in the upper and then the lower house without recorded debate by 21 April, and it came into force when assented to on 28 May 1858. The enacting clause specified that this was a 'declaratory' statute: "BE IT THEREFORE DECLARED AND ENACTED ..." The Act was an openly retrospective statute to quash the "doubts" that had been raised "as to what Acts of the Imperial Parliament" passed before 14 January 1840 were in force in the Colony. As a result of this enactment, its re-enactment as the English Laws Act 1908, and the continuation of its reception provision by the Imperial Laws Application Act 1988, the reception of English law as New Zealand law remains firmly fixed as commencing from 14 January 1840. On the specific matter at issue in McLiver v Macky, the Wills Act 1837 was deemed in force in New Zealand from 14 January 1840 and it was included in the schedule of imperial statutes still in force when the Imperial Laws

47 "Supreme Court" The Southern Cross (Auckland, 18 November 1856) at 4.

48 See Macdonald in this volume.

49 "New Zealand Parliaments and Sessions, 1854-1949" in GH Scholefield (ed) New Zealand Parliamentary Record 1840-1949 (Government Printer, Wellington, 1950) at 68. 
Application Act 1988 was passed. It ceased to be part of New Zealand law when the Wills Act 2007 came into force.

The precise reasons for choosing 14 January 1840 as the reception date remain as a mystery for future researchers to unravel. On my analysis there are at least seven different dates that may lay a more or less plausible claim to be the anniversary of the inception under colonial law of New Zealand as a polity in the British Empire. In addition to those seven dates, there are a more than fifty dates between 6 February and 3 September when the Treaty of Waitangi was signed by numerous leading chiefs, women and men, in many locations on all main islands. ${ }^{50}$ Imperial government approval of the entire process of obtaining Maori signatures to the Treaty of Waitangi did not occur until a despatch dated 30 March 1841 - well after New Zealand had been erected as a colony separate from New South Wales.

The seven leading colonial law commencement date possibilities are: ${ }^{51}$

(i) 15 June 1839 when Letters Patent enlarged the jurisdiction of the Governor of New South Wales to include the New Zealand islands;

(ii) 14 January 1840 when Governor Gipps privately swore in Hobson as Lieutenant Governor and signed three proclamations relating to the New Zealand dependency; (iii) 19 January 1840 (after Hobson's departure from Sydney) when the New Zealand proclamations were published officially in Sydney;

(iv) 30 January 1840 when Hobson arrived in the Bay of Islands and issued a proclamation stated that he had assumed office as Lieutenant Governor of the British settlements in progress in New Zealand;

(v) 21 May 1840 when Hobson issued two proclamations asserting full British sovereignty over the New Zealand Islands - claiming the North Island by cession under the Treaty of Waitangi, and other islands by mere assertion (later justified as on the basis of discovery);

(vi) 16 June 1840 when the New South Wales legislature applied New South Wales law to New Zealand (prior to knowledge in Sydney of Hobson's May proclamations); and

(vii) 2 October 1840 when the imperial government in London arranged for Hobson's May proclamations to be published by authority in its Gazette.

The lack of recorded parliamentary debate in 1858 means that there is no way of knowing why the 14 January date was chosen by Whitaker and his colleagues to be the deemed reception date.

50 Claudia Orange The Treaty of Waitangi (Allen and Unwin/Port Nicholson Press, Wellington, 1987) at 6263.

51 Williams "The Foundation of Colonial Rule", above n 2, at 56; Williams "The Annexation of New Zealand, above n 41, at 41-45. 
However, further research into the background to the Supreme Court Ordinance 1841 and the Supreme Court Ordinance 1844 may unearth some relevant information. The imperial authorities disallowed the 1841 Ordinance, for reasons explained in Damen Ward's article, and the Supreme Court Ordinance 1844 was passed in its stead. ${ }^{52}$ Both ordinances included a provision that is the earliest instance I know of for a specific official mention of 14 January 1840 . However, as a matter of statutory interpretation, I am not convinced that these mentions are unambiguous as the choice of a date for the general reception of English laws and statutes of general application relevant to the circumstances of the Colony. Section 6 of the 1841 Ordinance and section 8 of the 1844 replacement are identical:

The Court shall not take cognizance of any criminal case where the offence shall have been committed previous to the fourteenth day of January, one thousand eight hundred and forty.

This provision is, on its face, specific only to criminal cases. My assumption is that the date restriction was mentioned in relation to criminal cases because this new legislation brought to an end the claimed jurisdiction of New South Wales courts for certain crimes committed in New Zealand when New Zealand was previously deemed to be "not within His Majesty's Dominions". That criminal jurisdiction had been claimed and indeed exercised on occasions by New South Wales courts under imperial legislation of 1817 (57 Geo III c 53 [Murders Abroad Act]), 1823 (4 Geo IV 96 [New South Wales Act]) and 1828 (9 Geo IV c 83 [Australian Courts Act]). ${ }^{53}$ By implication, it seems to me, the other jurisdictions granted to the Supreme Court as a fused jurisdiction court in the new Colony were not necessarily restricted only to matters arising after 14 January 1840 and could be invoked for matters arising before then. These were common law jurisdictions of Queen's Bench, Common Pleas and Exchequer in section 2; the equitable jurisdiction of the Lord High Chancellor in section 3; the jurisdiction of ecclesiastical courts in England with respect to intestacy and the validity of wills of personal property in section 4 - though with a more compendious wording in the 1844 version; and a jurisdiction in respect of infants, and of idiots, lunatics and others of unsound mind in section 4. The 1844 Act added new provisions for an Instance Court of Vice Admiralty (section 6) and a criminal jurisdiction in that Vice-Admiralty court "as if the same had been committed on the land" (section 7). This admiralty jurisdiction might have been highly relevant to the issues discussed by Shaunnagh Dorsett in her conference contribution, but seemingly were not found to be so. ${ }^{54} \mathrm{Be}$ that as it may, certainly it is the case that 14 January 1840 was given a measure of official significance in the untidy legal transition of the New Zealand islands from being "not within His Majesty's Dominions" to being a dependency of New South Wales prior to being erected as a separate Colony.

52 Ward in this volume.

53 Williams "The Foundation of Colonial Rule", above n 2, at 55. See EJ Tapp Early New Zealand: A dependency of New South Wales, 1788-1841 (Melbourne University Press, Carlton, 1958) at 71.

54 Dorsett in this volume. 
Finally, modern readers may be surprised that 6 February seems not to have been a serious contender as the deemed date for the application of English law in New Zealand. A final fragment of legal history to conclude this article I derive from the research of Ned Fletcher, co-author of one of the conference papers. ${ }^{55}$ This indicates that Gipps may not have had a fixed prior position on these matters, or at least that he modified his thinking on how and when English law was applicable in New Zealand during the mid-1840 debates on statutes to be applied to the new dependency. Busby, the leading subject of the paper presented by Dame Sian Elias, was one of those who gave notice of his intention to speak against the New Zealand Land Claims Bill presented by Governor Gipps to the New South Wales Legislative Council in late May 1840. Busby's attack on this Bill was based on the pre-existing rights that he and others claimed to possession of land acquired in some way from Maori in pre-colonial New Zealand. Busby put the Treaty of Waitangi (in his translation of its Maori text) at the forefront of his arguments. Fletcher's researches in the New South Wales parliamentary archives indicate that the preamble to the Bill on the application of New South Wales law in New Zealand was amended in Gipps' own handwriting between introduction and debate in the Council. The preamble as first drafted began: "Whereas Her Majesty hath lately acquired the Sovereignty of a great portion of the Islands of New Zealand, and it hath pleased Her Majesty to place the same, under the Government of New South Wales ..." The Governor's revised wording changed both the tense and the sense of the preamble: "Whereas Her Majesty hath been pleased to annex Her Majesty's Dominions in the Islands of New Zealand to the Government of New South Wales ...".

Gipps had received a memorandum from one of the Colony's judges, John Walpole Willis, which referred to American case law on the rights acquired by the British Crown by discovery and which also seemed to suggest that New Zealand was already British by right of Cook's discovery. Fletcher's view is that Gipps probably realised that it was going to be difficult for him to rely on American law as declaratory of English law on Crown pre-emption and native title applicable to New Zealand if the basis of British sovereignty was the Treaty of Waitangi. The changes to the Laws Bill were designed to shore up his position and to ensure he was not accused of any inconsistency later. This approach was maintained in his speech on the Land Claims Bill, which studiously avoided any mention of the Treaty as the foundation of British sovereignty in New Zealand. ${ }^{56}$

In contemporary New Zealand commentaries on law and politics the Treaty of Waitangi is often described as a foundation or a cornerstone for the origins of the New Zealand nation. The only national day recognised in New Zealand law under the Waitangi Day Act 1976 is 6 February. It may

55 Fletcher and Elias in this volume.

56 Letter from E Fletcher to DV Williams (12 July 2010); New South Wales Parliamentary Archives, Sydney, Legislative Council Manuscript Records, 3rd Council, 12th Session, 28 May-16 December 1840, Box 16, Public Acts. 
be something of a surprise, therefore, that a judge in 1856 was unsure what the lawful basis was for claims that New Zealand was a British territory, but that he was sure that the Treaty of Waitangi confirmed Maori land rights rather than ceded sovereignty. It may also be a surprise for many to learn of the importance in our legal history of the short period that New Zealand was a dependency of the Colony of New South Wales. Yet, for reasons discussed in this article, the legal fact (or legal fiction) is that the entire body of English law relevant to the circumstances of New Zealand is deemed to have applied here from a date prior to the arrival in the Bay of Islands of Hobson, the British consul appointed to treat with Maori. Moreover, no decision-maker or judge in imperial or colonial administrations in 1839, 1840,1841, 1844, 1856 or 1858 is on record as suggesting that the reception of English law as the law of the Colony of New Zealand had anything at all to do with the Treaty of Waitangi.

An Auckland jury's verdict in 1856 that the unexecuted copy of a will of Hugh McLiver was a valid will was arrived at in the face of the clearest possible directions from the judge to the contrary. This surprising jury verdict led to a carefully argued motion for a new trial, and then a perhaps even more surprising judicial finding that the Wills Act 1837 did not apply in New Zealand in 1856. Thanks to the New Zealand Law Foundation and the Victoria University of Wellington Lost Cases Project, the long lost pre-history of the English Laws Act 1858 has now been opened up to modern scrutiny. 